\title{
Does Building Trust Enhance the Effect of E-Leadership on the Organizational Commitment? Empirical Evidence from Islamic Banks in Palestine
}

\author{
Raed A. M. Iriqat ${ }^{1} \&$ Dana M. S. Khalaf ${ }^{2}$ \\ ${ }^{1}$ Faculty of Administrative and Financial Sciences, Arab American University, Palestine \\ ${ }^{2}$ Faculty of Graduate Studies, Arab American University, Palestine \\ Corresponding address: Raed A. M. Iriqat, Business Administration Department, Faculty of Administrative and \\ Financial Sciences. Arab American University, P. O. BOX 240, Jenin-West Bank, Palestine. Tel: 970-595-386-355. \\ E-mail: raed.iriqat@aauj.edu; raed.iriqat@hotmail.com
}

Received: July 21, 2018

Accepted: August 8, 2018

Online Published: August 15, 2018

doi:10.5539/mas.v12n9p98

URL: https://doi.org/10.5539/mas.v12n9p98

\begin{abstract}
This study aims to investigate the enhancing role of building trust in the effect of e-leadership on an organizational commitment to the virtual teams in Islamic banks in Palestine. Furthermore, the article has found that: (1) Eleadership is significantly related to building trust and organizational commitment of the virtual teams in Islamic Banks in Palestine. (2) The three dimensions of e-leadership (engage, execute, and elastic) significantly predicted organizational commitment (3) building trust is significantly enhancing the effect of E-leadership on the organizational commitment in Islamic Banks in Palestine. Based on the results, the scholars recommend that banks should develop the banking procedures to be more elastic and more suitable for banking services to facilitate bank transactions.
\end{abstract}

Keywords: e-leadership, organizational commitment, building trust, islamic banks, palestine

\section{Introduction}

The worldwide economy is undergoing a major change with the developments in the information technology. New technology has the potential to impact the distribution of power and the development of relationships in the organization. Thus, the development of technological, knowledge and the telecommunication in the world in the business market became necessary to implement a new system of traditional leadership. Leadership encompasses two areas - research and skills. According to Lussier and Achua (2015), leadership as a skill involves how individuals are able to guide others (individuals, teams). On the other hand, leadership, per meritocratic thinkers, is more democratic (Cano, 2010). Tzu (2005) argued that leadership encompasses discipline, intelligence, humaneness, trustworthiness, and courage.

Since current organizations are becoming globalized, E-leadership is increasingly needed in order to meet common goals. Common technologies utilized in E-leadership involve online collaboration software, Wi-Fi, e-mail, video conferencing, and cell phones. However, there are issues in relation to the integration of technology for organizations, as well as the learning curve faced by employees. E-leadership is considered to be a social influence process that is mediated by technology. According to Avolio et al., (2003), E-leadership is a social effect by information technology to make a change in position, feelings, thinking, behavior, and performance with individuals. It's requested by the organization for a team to use the new communication technology is called a virtual team and the new technology need a new style of leadership which called E-leadership. In addition, Eleadership is characterized as a social impact process intervened by ICT to deliver an adjustment in states of mind, emotions, considering, conduct, and execution with people, gatherings, and associations (Barrett, 2011).

The importance of enhancing the role of e-leadership on organizational commitment and building trust is to help maximizing effectiveness and efficiency to achieve organizational goals. Thus, the main objective of this paper is to identify the mediating role of building trust in the impact of E-leadership on organizational commitment in Palestinian Islamic Banks. The paper structure divided into six sections: section one include the introduction, and significance of the study, whereas, section two includes a literature review and developing hypotheses, in addition, section three displays methodology. Section four includes testing hypotheses, and finally, section five shows the 
conclusion and recommendations.

\section{Literature Review and Developing Hypotheses}

Many debates regarding leadership are based on different viewpoints, specifically the contrasts that exist between Eastern leadership approaches and Western leadership approaches. Academically, leadership is defined as a social influence process where one person is able to obtain aid and support from other individuals in order to accomplish a common task, whereas non-academically, leadership involves personal power (Chin, 2015). Leadership studies have led to a wide berth of theories, such as those relating to traits (Gregoire \& Arendt, 2014), situational interactions (Lu, Shen, \& Williams, 2014), function (Bums, 2016), behavior (Lee, Gillespie, Mann, \& Wearing, 2010), power (Vaccaro, Jansen, Van Den Bosch, \& Volberda, 2012), vision and values (Barrett, 2011), charisma (Graetz, 2000), and intelligence (Carraher, 2013) gender (Iriqat, 2017).

E-leadership is designed to produce changes in performance, thinking, feelings, behavior, and/or attitudes for recipients (such as groups, individuals, or entire organization times) to provide guidance in reaching a common goal (Avolio et al., 2014). In fact, E-leadership involves enhancing organizational members' relationships in such a way that allows work to be mediated using technology. This means that communications, information collection, and information dissemination occur through information technology, as opposed to traditional leadership, which focuses on face-to-face interactions. Using technology, leaders can lead from a distance and interactions are conducted solely through technological means. However, E-leadership and traditional leadership may have the same style and content. One of the most significant causes of this ability is the development of visual technological interactions (such as video conferencing). Another major similarity is in relation to participative leadership, which allows individuals to be more participative in decision-making. It is important for members to be involved in the decision-making processes, which allows E-leadership to be beneficial through the use of virtual anonymous chats and polls. Moreover, E-leadership can be inspiring (such as in traditional transformational leadership) through the use of e-mail to convey visions, accomplishments made by the team, or excitement over new goals (Li et al., 2016).

\subsection{The Dimensions of E-leadership}

There are several models of E-leadership, such as four E's Leadership, five E's Leadership, and six E's Leadership. The four E's refer to vision, relation, systems, and reflective (Colbert, Judge, Choi, \& Wang, 2012). In this context, vision refers to the goal and purpose of the team creation. Relations the creation of relations among the leader and team members. Systems refer to the relationship that exists among different team members. Reflectively refers to the ability to look back on decisions and situations, allowing negative and positive outcomes to guide future actions (Colbert et al., 2012). Moreover, the five dimensions of leadership, including character, role, action, context, and story (Chua \& Chua, 2017). In this consideration, a character refers to the traits used to encourage the team. Role refers to the interactions of the leader with the team, as well as availability to the team. Action refers to the actions taken by the leader in guiding the team. Context involves the reasoning for conducting a particular action. The story refers to the impact held by the activity of leadership (Chua \& Chua, 2017), while, the six e's in E-leadership model emphasizes envision, engage, energize, empower, execute, and elastic (Blau \& Presser, 2013; Iriqat \& Khalaf, 2017).

Envision/ vision involves the development of a goal, which is both powerful and compelling. Therefore, envision is important because it provides a goal for the team, as well as for the leader. As a result, it is increasingly possible for the leader to lead the team in the accomplishment of the goal and micro goals if needed (Formisano, Fedele, \& Antonucci, 2015; Noor, 2013; Sansone \& Formisano, 2016; Iriqat \& Khalaf, 2017;Ivanova \& Arenas, 2014; J. Jameson, 2013; Menichetti, 2017) in (Desveaux, 2015) determined the envision as e-leadership dimension. Engage is related to envision because it emphasizes the ability of team members to voice their opinions regarding the proposed goal. Engage is important in relation to brainstorming, which allows the team to develop the most effective process to complete a task. This could involve steps towards a major goal or innovation of a new process that is more effective in relation to the capabilities of the team. (Hüsing et al., 2013; Niyazmand \& Feizi, 2016; Ochara, 2013; Iriqat \& Khalaf, 2017; Carreño, 2014; J. Jameson, 2014; Mishra, Henriksen, Boltz, \& Richardson, 2016; Suliman, Klaber, \& Warren, 2013) used the engage as an e-leadership dimension. Energize is related to engage by encouraging the team to stand for something - the goal and integrity. The focus in this component is to ensure the team believes in the goal. Energize is important because it promotes motivation for the team and is most evident if the leader is excited about the goal. Thus, energize involves making the goal worthwhile for the team. (Cherian \& Farouq, 2013; Halbach \& Gong, 2013; Richter \& Wagner, 2014; Iriqat \& Khalaf, 2017; Brown, Czerniewicz, Mayisela, \& Huang, 2016; J. Jameson, 2015; Sinclair, 2014; Remus, 2016) determined the energize as an e-leadership dimension. Empower refers to giving decision-making capabilities to individuals and showing trust that the team is making effective decisions. In this way, empower allows the team to act on their own and 
make decisions that may lead to improved outcomes. Empower also allows the team to be able to assist others, such as customers, through innovative solutions to problems. (Chatterjee \& Kulakli, 2015; Javed et al., 2014; Kesič \& Shah, 2017 ; Iriqat \& Khalaf, 2017; Bowen et al., 2013; Ekren et al., 2017; Kong, Chan et al., 2014; Keijser et al., 2016) determined the empower as e- leadership dimension. Execute refers to taking action to meet the goal, as well as evaluating the results. Execute occurs both during the goal and following the goal. This allows the team to assess if the process used was effective, what could have been done differently, and what was done right. In this way, it is possible for the team to establish changes within the team, such as changes in focus, changes in team members, or changes in processes used. (Chalterjee \& Kulakli, 2015; Javed et al., 2014; Kesič \& Shah, 2017 ; Iriqat \& Khalaf, 2017 ;Bowen et al., 2013; Ekren et al., 2017; Kong et al., 2014; Bowen et al., 2013; Ekren et al.,2017; Kong, Chan, Huang, \& Cheah, 2014; Keijser et al., 2016) determined the execute as e- leadership dimension. Elastic refers to being flexible in changing the goal in order to meet the changing roles of the team. Elastic is beneficial when the customer changes their requirements because the team has been prepared for possible changes and can easily redirect their processes to meet the changes. At the same time, elastic is important if there are changes within the organization (Bowen et al., 2013; Colbert et al., 2012; J. Jameson, 2013). (Belias \& Koustelios, 2014; Mozammel \& Haan, 2016; Zareen et al., 2015; Iriqat \& Khalaf, 2017; Beadle, 2015; Blau \& Presser, 2013; Slykhuis \& Lee, 2016; Bandara et al., 2017) determined the elastic as e- leadership dimension

\subsection{Building Trust and Organizational Commitment in Virtual Teams}

The digitalized business world changes strikingly the setting of driving where e-connections turn out to be increasingly basic in innovation supported the administration. This change challenges day by day initiative work as to social abilities and types of association. Trust and trust-building is a fundamental asset, immaterial source, and expertise as an establishment for community-oriented activities in associations and their authority. The scientists examined e-leaders' perspectives of the new e-initiative setting concentrating particularly on put stock in working in devotees (Savolainen, 2014).

The constrained proximal correspondence between virtual colleagues can make an absence of trust among individuals which can essentially lessen the adequacy of these groups. Consequently, this investigation was directed to inspect the connection amongst trust and virtual group viability by investigating the interceding impact of information sharing (Pangil \& Moi Chan, 2014), Trust has been established to be a huge indicator of virtual group adequacy. Be that as it may, this paper demonstrates the impact of various sorts of trust and the part of learning to partake in intervening the connection amongst trust and virtual group viability.

Organizational commitment (OC) refers to a person's affective reactions to characteristics of his employing organization (Cook et al., 1980). Miller and Lee (2001) show that the OC is the acceptance of organizational objectives by staff and their willingness to make efforts on behalf of the organization. In addition, another definition of OC through Arnold (2005, p 625) "Relative strength that determines the individual participant in the organization". Porter et al. (1974); Meyer \&Allen (1997); Wasti (2005); and Iriqat (2016) show that there are three sorts of OC (Affective commitment, Normative commitment, and Continuance commitment). moreover, Avolio et al., (2004) shown that OC depends on personal and organizational factors.

Empiricaly, Iriqat, and Khalaf (2017) found that there is a positive significant relationship between E-leadership dimensions (i.e. Envision, engage, energize, empower, execute, and elastic), as well as, they found that foreign banks in Palestine used the concept of E- leadership in high level, moreover, Mozammel \& Haan (2016) found that the transformational administration is required today to encourage worker engagement and increment profitability also is positively related to followers' level of empowerment (Avolio et al., 2004; Ismail et al., 2011). Salas et al. (2015) found the relationship between shared group authority and group execution was not influenced by the level of virtually. Zareen et al. (2015) argued that worker inspiration is crucial for the achievement of hierarchical objectives. This examination inspects the esteem and effect of value-based, transformational and Laissez-faire administration styles on the inspiration of saving money division representatives. Through a study of Jordanian banks, an analysis was conducted regarding the challenges of leading team members across geographic areas. The model tested in the study conducted by Qteishat (2014) was the technology acceptance model, regarding E-leader adoption. The major components of the technology acceptance model have perceived usefulness and perceived ease of use (Cheung \& Vogel, 2013). In the case of Jordanian banks, E-leadership adoption was perceived in a positive manner, suggesting that there was a high degree of perceived usefulness and perceived ease of use. Moreover, the study showed that there was a high level of reliability and responsiveness. Ismail et al.,, (2011) showed that empowerment and transformational leadership are significantly related with the OC. In addition, Olaisen and Revang (2017) create social connection developing trust and offer to learn through online innovation stages without disconnected social cooperation. 
Cook et al. (1980) argued trust among individuals and groups within an organization is very important in building the long-term organizational stability. Building trust has recently been recognized as one of the main tasks of the leaders (Yukl, 2010), and it is a key concept in a virtual team that would help bridge the gap between the challenges of virtual teams and team effectiveness (Khan, 2012). Trust is faith in and loyalty to the leader (Podsakoff et al., 1990, p113). In addition, trust refers to expected by an individual or group that the word, verbal or written speech or promise of another individual or group is reliable. Leaders can create a reliable business climate; enhance the vitality and competitiveness of organizations through 'leadership by trust' Trust is an intangible resource also a skill for leaders. Trust may open up an opportunity to acquire knowledge, economic resources, and relational organizations. As well as a mechanism for social coordination to maintain loyal relationships those do not deteriorate or break easily. (Savolainen, 2011).

Iriqat (2016) shows that OC is a significant factor in promoting employee's performance, while Laschinger et al., (2009) argued that affective commitment has been positively correlated to job performance, job satisfaction, and turnover. Hurley (2012) and Cook et al., (1980) confirmed that trust empirically correlated to OC, on another hand, the importance of trust has been studied by Hurley (2012) found that it has a positive impact on the employee trust in the job performances as well as engagement. Thus, trust in the leadership determines the effectiveness of the team and organization. It is the responsibility of the e-leadership to foster trust in the virtual team for collaborative behavior given the challenges of a virtual setting of how should e-leadership build trusting relationships within the virtual team. Perry (2004) found that trust and OC are not empirically related to each other.

The link between transformational leadership and OC was discussed in the large body of empirical studies, and they evidenced that there is a positive relationship among both variables (Walumbwa et al., 2005; Emery et al., 2007; Avolio et al., 2004). On another hand, Iriqat \& Khalaf (2017) pointed out that the dimensions of E-leadership are empirically correlated with the OC of virtual teams. In addition Aina \& Verma (2016) research about the impact of leadership style on OC, it showed that there is a significant relationship between the leadership style and the OC of middle managers. Also, it was showed that the OC is higher for the average managers who showed senior managers the transformational leadership style of those who have transaction leaders and experiences. Based on the theoretical and empirical literature, researchers develop the following hypotheses to answer the main question: Does building trust enhance the effect of E-leadership on the OC in Islamic banks in Palestine?

H0-1: Perception E-leadership does not significantly related to building trust and organizational commitment of the virtual teams in Islamic Banks in Palestine.

H0-2: Building trust does not significantly enhance the effect of E-leadership on the organizational commitment in Islamic Banks in Palestine.

\section{Methodology}

\subsection{Data Collection}

This paper based on the structured questionnaire to gathering the primary data from the employees in the Palestinian Islamic banks. Our questionnaire consists of four parts, the first part E-leadership in this part it has six subparts, envision is structured into eight items, sample item: Increases cooperation with my coworkers, engage has six items, sample item: Boosts my personality in provided services, energize six items, sample item: Shows my opinion about service mechanics, empower twelve items, sample item: Increases my ability to decision making, execute has eight items sample item: Minimizes time to complete the task, and Elastic has seven items, sample item: better amendment in procurers. The second part is an OC, it is structured into thirteen items, sample item: I do not think of leaving my job at all. Part three is building Trust which has twelve items, sample item: I feel comfortable towards coworker, and the last section consists of demographic information about the respondents which has six variables, the questionnaire is a 5-Likert scale questionnaire.

\subsection{Reliability Analysis}

This study used the Cronbach Alpha test to calculate the reliability score, used for the instrument before and after the main survey. The test was carried out in this study through applied a pilot study by distributed 30 questionnaires on a sample similar to the target sample with similar characteristics. The test was conducted on each of the 6e's Eleadership dimensions assessed by the questionnaire for e-leadership (0.952), scale for OC (0.905), and building trust (0.923). The alpha coefficient exceeded the level of 0.70 for the scales in each dimension assessed by the questionnaire, which is considered the minimum level of reliability internal consistency of a scale (Adams \& Lawrence, 2014)

\subsection{Population and Sample}

The population in this study is limited to the employees of Islamic banks in Palestine, which are three banks with 
more than fifty branches. Table (1) represents the number of employees due to banks. In addition, the study applies a random sample, in order to ensure the equitable offer for all targeted Islamic Banks in Palestine. The sample size is identified according to Daniel (1999). The minimum sample size was 244 employees. 244 questionnaires were distributed, the response rate was 0.807 (197 participants), which is a high rate. $69 \%$ of participants were male, whereas 31\% were female, $41.6 \%$ from Arab Islamic bank, 53.8\% from Palestinian Islamic bank, and 4.6\% from a safe bank. The experience of participants was distributed between low to high experiences, $34.5 \%$ of participants have low experience (less than 3 years), 30.2\% in the category of (3-6) year of experience, 23\% of them, their experiences exceed 10 years $m$ while less than $12 \%$ in category of (7-10) year of experience.

Table 1. Population of the Study

\begin{tabular}{lll}
\hline Bank & Number of Employees & Percentage \\
\hline Arab Islamic Bank & 411 & $41.5 \%$ \\
Palestine Islamic Bank & 568 & $57.3 \%$ \\
Safa Bank & 12 & $1.2 \%$ \\
Total & 991 & $100 \%$ \\
\hline
\end{tabular}

SOURCE: OWN

\subsection{Conceptual Model}

To answer the study question: Does building trust enhance the effect of E-leadership on the organizational commitment (OC). Researchers develop the empirical model. Our model includes three types of variables: independent variables E-leadership dimensions (Envision, Engage, Energize, Empower, Execute and Elastic), building trust defined as mediator variable, and OC as the dependent variable. Figure (1) explains the relationships among study variables.

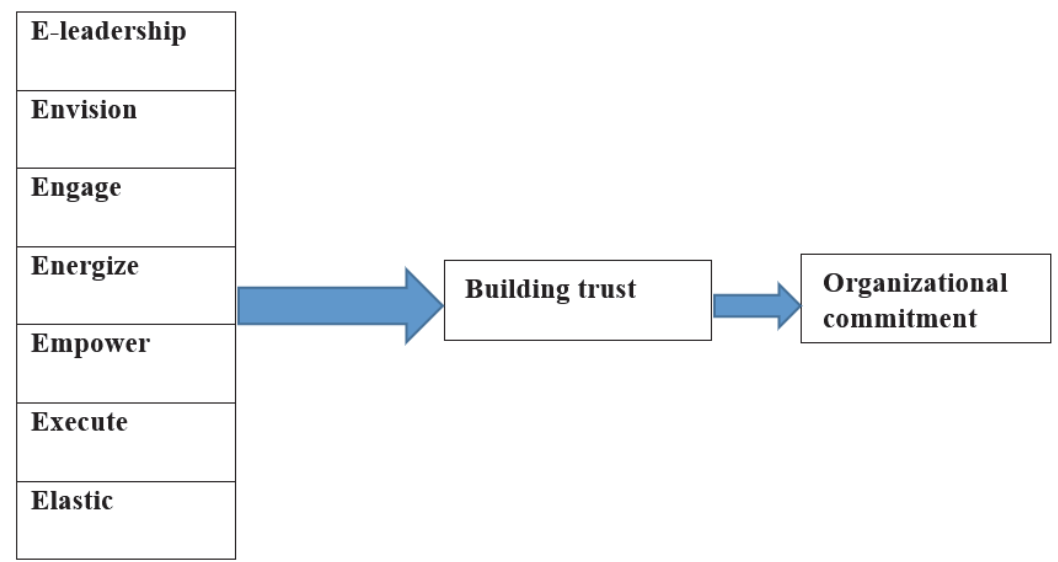

Figure 1. Conceptual Model

\section{Testing Hypotheses}

H0-1: Perception E-leadership does not significantly related to building trust and organizational commitment of the virtual teams in Islamic Banks in Palestine.

Table (2) shows descriptive statistics the variables used in the model. It also represents the mathematical means, standard deviations, and Pearson correlation coefficients. As shown in below table, E-leadership achieved a high level of mathematical mean (4.2215), and small standard deviation (0.32063), as well as, building trust moreover achieved a high level of mathematical mean (4.3143), and small standard deviation (0. 50201), also, OC also realized a high level of mathematical mean (4.3262), and small standard deviation (0.46707). Otherwise, the six dimensions of E-leadership achieve a high level with mathematical means ranged between (4.26 and 4.37). Due to the findings, it's obvious that the Islamic banks live in an effective e-business environment.

In addition, Pearson correlation matrix among E-leadership dimensions, E- leadership, building trust and OC of 
virtual teams is presented in table (2). The results show that there is a strong significant positive relationship between the total value of E- leadership and each of envision, engage, energize, empower, execute, and elastic, where $(\mathrm{r}=0.805, \mathrm{p}<0.01),(\mathrm{r}=0.743, \mathrm{p}<0.01),(\mathrm{r}=0.753 \mathrm{p}<0.01),(\mathrm{r}=0.872 \mathrm{p}<0.01),(\mathrm{r}=0.815, \mathrm{p}<0.01)$, and $(\mathrm{r}=0.675, \mathrm{p}<0.01)$ respectively. In addition, there is a significant positive relationship among E- leadership and both of building trust and $\mathrm{OC}$ where $(\mathrm{r}=0.461, \mathrm{p}<0.01)$, and $(\mathrm{r}=0.498, \mathrm{p}<0.01)$ respectively, also the building trust is empirically correlated to OC where $(\mathrm{r}=0.699, \mathrm{p}<0.01)$.

Moreover, table (2) shows that all e-leadership dimensions are empirically correlated to each other. Thus, we accepted the H0-1, that the Perception of E-leadership is directly related to building trust and OC of the virtual teams in Islamic Banks in Palestine. The results of the correlation coefficients proved that there is the existence of the correlation among OC, six e-leadership, and building trust.

Table 2. Correlation Matrix among Study Variables

\begin{tabular}{lllllllllll}
\hline Dimensions & $\mathrm{M}$ & $\mathrm{S} . \mathrm{D}$ & 1 & 2 & 3 & 4 & 5 & 6 & 7 & 8 \\
Envision & 4.27 & .479 & 1 & & & & & & & \\
Engage & 4.27 & .3823 & $.568^{* *}$ & 1 & & & & & & \\
Energize & 4.26 & .452 & $.552^{* *}$ & $.587^{* *}$ & 1 & & & & & \\
Empower & 4.35 & .398 & $.580^{* *}$ & $.559^{* *}$ & $.599^{* *}$ & 1 & & & & \\
Execute & 4.37 & .380 & $.551^{* *}$ & $.467^{* *}$ & $.523^{* *}$ & $.731^{* *}$ & 1 & & & \\
Elastic & 4.32 & .424 & $.466^{* *}$ & $.417^{* *}$ & $.347^{* *}$ & $.471^{* *}$ & $.523^{* *}$ & 1 & & \\
E-Leadership & 4.2215 & .32063 & $.805^{* *}$ & $.743^{* *}$ & $.753^{* *}$ & $.872^{* *}$ & $.815^{* *}$ & $.675^{* *}$ & 1 & \\
Building Trust & 4.3143 & .50201 & $.331^{* *}$ & $.230^{* *}$ & $.256^{* *}$ & $.458^{* *}$ & $.560^{* *}$ & $.251^{* *}$ & $.461^{* *}$ & 1 \\
Organizational commitment & 4.3262 & .46707 & $.364^{* *}$ & $.187^{* *}$ & $.263^{* *}$ & $.467^{* *}$ & $.573^{* *}$ & $.400^{* *}$ & $.498^{* *}$ & $.699^{* *}$ \\
\hline
\end{tabular}

Source: Own

Note: $*$ : confidence level at $0.05, * *$ : confidence level at 0.01 .

\section{H0-2: Building trust does not significantly enhance the effect of E-leadership on the organizational commitment in Islamic Banks in Palestine.}

To test the second hypothesis, this study employs hierarchical multi-regression analysis to investigate the mediating role of building trust in the effect of e-leadership dimensions on OC. Hierarchical regression analysis includes two steps. Step (1) presents model number one, to identify the impact of E-leadership dimensions on OC, and step (2) presents model number two, to identify the impact of both of E-leadership dimensions and building trust on OC.

Table (3) shows the model summary for two models, first model refers to the first step in the hierarchical regression analysis when the six dimensions of e-leadership are used as a predictor, whereas the second model refers to the second step in the hierarchy when the six dimensions of e-leadership and building trust are used as a predictor, in the labelled column R presents simple correlation among six dimensions of e-leadership and OC (0.611) in the first model, while, in the second model R presents multiple correlations among e-leadership dimensions, building trust and OC (0.757). R square for the first model indicates that e-leadership dimensions account for $37.3 \%$ of the variation in OC, whereas, by adding a moderate variable (building trust) in the second model, the value of R square increase to $57.3 \%$ of the variation of OC. Therefore, the addition of the building trust significantly enhances prediction of OC added extra (0.573-0.373) $20 \%$ of the variation of OC. Table (3) shows that $(\mathrm{F}(6,190)=18.826$, $p=.000)$ for the initial model, while the second model $(\mathrm{F}(7,189)=36.288, p=.000)$. That's mean that building trust is significantly enhanced prediction $\left(R^{2}\right.$ change $\left.=0.201 . p=.000\right)$.In another word, building trust is significantly enhancing the effect of E-leadership on the OC in Islamic Banks in Palestine.

Table 3. Model Summary

\begin{tabular}{|c|c|c|c|c|c|c|c|c|c|}
\hline Model & Sum of squares & $\mathrm{DF}$ & Mean Square & $\mathrm{F}$ & Sig. & $\mathrm{R}$ & R2 & R2 Change & Sig. F Change \\
\hline 1 Regression & 15.942 & 6 & 2.657 & \multirow[t]{3}{*}{18.826} & \multirow[t]{3}{*}{$.000^{\mathrm{b}}$} & \multirow{3}{*}{$.611^{\mathrm{a}}$} & \multirow{3}{*}{.373} & \multirow{3}{*}{.373} & \multirow[t]{3}{*}{.000} \\
\hline Residual & 26.817 & 190 & .141 & & & & & & \\
\hline Total & 42.759 & 196 & & & & & & & \\
\hline 2 Regression & 24.517 & 7 & 3.502 & \multirow{2}{*}{36.288} & \multirow[t]{2}{*}{$.000^{\mathrm{c}}$} & \multirow{2}{*}{$.757^{\mathrm{b}}$} & \multirow{2}{*}{.573} & \multirow{2}{*}{.201} & .000 \\
\hline Residual & 18.242 & 189 & .097 & & & & & & \\
\hline
\end{tabular}




\begin{tabular}{lll}
\hline Total & 42.759 & 196 \\
\hline
\end{tabular}

Source: Own

Note: confidence level at 0.05 .

Future more, the results of the regression analysis shown partial confirmation for the impact of six dimensions of e leadership in OC in first model in table (4). Beta coefficients for the three predictors were engage, $\beta=-.236, t=$ $-2.460, p=.015$; execute, $\beta=.553, t=5.010, p=.000$; and Elastic, $\beta=.161, t=2.074, p=.039$, of all of the eleadership dimensions that positively affect OC in the first model, execute is the most important.

whereas, the regression analysis in the second model indicated that building trust significantly predicted OC ( $\beta$ $=.505, t=9.426, \mathrm{p}=0.00)$ in addition to partial effect of e-leadership dimensions, that Beta coefficients for the three predictors were engage, $\beta=-.197, t=-2.483, p=.014$; execute, $\beta=.206, t=2.098, p=.037$; and Elastic, $\beta$ $=.204, t=3.165, p=.002$. Of all of the variables that positively affect OC in the second model, building trust is the most important.

Table 4. Summary of HRA for Independent Variables Predicting Organizational Commitment

\begin{tabular}{|c|c|c|c|c|c|}
\hline \multirow[t]{2}{*}{ Mod } & & \multicolumn{2}{|c|}{ Unstandardized coefficient } & \multirow[t]{2}{*}{ T-value } & \multirow[t]{2}{*}{ Sig. } \\
\hline & & $\mathrm{B}$ & S.E & & \\
\hline \multirow[t]{7}{*}{1} & Constant & 1.277 & .371 & 3.445 & .001 \\
\hline & Envision & .097 & .078 & 1.243 & .216 \\
\hline & Engage & -.236 & .096 & -2.460 & .015 \\
\hline & Energize & -.056 & .082 & -.686 & .493 \\
\hline & Empower & .178 & .110 & 1.608 & .109 \\
\hline & Execute & .553 & .110 & 5.010 & .000 \\
\hline & Elastic & .161 & .078 & 2.074 & .039 \\
\hline \multirow[t]{8}{*}{2} & Constant & .632 & .314 & 2.013 & .046 \\
\hline & Envision & .060 & .064 & .925 & .356 \\
\hline & Engage & -.197 & .080 & -2.483 & .014 \\
\hline & Energize & -.006 & .068 & -.092 & .927 \\
\hline & Empower & .075 & .092 & .819 & .414 \\
\hline & Execute & .206 & .098 & 2.098 & .037 \\
\hline & Elastic & .204 & .064 & 3.165 & .002 \\
\hline & Building trust & .509 & .054 & 9.426 & .000 \\
\hline
\end{tabular}

Source: Own

Note: Confidence level at 0.05 .

\section{Conclusion}

This paper aims to explore the mediating role of building trust in the impact of e-leadership in enhancing organizational commitment (OC) for the virtual teams in Islamic banks in Palestine. Using six dimensions of E leadership, the results support that : (1) E-leadership is significantly related to building trust and OC of the virtual teams in Islamic Banks in Palestine. (2) The three dimensions of e-leadership (engage, execute, and elastic) significantly predicted OC (3) building trust is significantly enhancing the effect of E-leadership on the OC in Islamic Banks in Palestine.

Based on the results of this paper, the scholars recommend that banking management focuses on developing the electronic abilities and skills for the directors through (envision, engage, energize, empower, execute and elastic) which increase OC and as well as increase the trust for the employees in banking sectors, as well as, give employee regular opportunities to enhance their professional skills, In addition, developing the banking procedures to be more elastic and more suitable for banking services to facilitate bank transactions. Furthermore doing researches on the effects of elastic of the leaders in building trust and clarifying execute procedures for the bank transactions which participate in building trust.

Even though the study has achieved its aims. This study has some limitations, firstly, size of the population, which limited in Islamic banks, therefore, to generalize the findings for Palestinian banking sector, the study should have participated at commercial banks. Secondly, the study aims to explore the overall e-leadership dimensions but not 
focused on some of them. Finally, limited empirical studies that explain the relationship among e-leadership dimensions, OC, and building trust. E-leadership is a potential topic for future studies, future studies are needed to investigate the interaction between e-leadership and several variables that related to organizational performance.

\section{References}

Aina, O. A., \& Verma, K. K. (2017). Effect of leadership style on organizational commitment. In Microelectronics Symposium (Pan Pacific), 2017 Pan Pacific (pp. 1-15). IEEE. An empirical study of the relationship between transformational leadership, empowerment, and organizational commitment.

Avolio, B. J., Sosik, J. J., Kahai, S. S., \& Baker, B. (2014). E-leadership: Re-examining transformations in leadership source and transmission. The Leadership Quarterly, 25(1), 105-131. https://doi.org/10.1016/J.LEAQUA.2013.11.003

Avolio, B. J., Zhu, W., Koh, W., \& Bhatia, P. (2004). Transformational leadership and organizational commitment: the Mediating role of psychological empowerment and the moderating role of structural distance. Journal of organizational behavior, 25(8), 951-968.

Avolio, B. J. \&Kahai, S. S. (2003). Adding the "E" to E-Leadership: How it May Impact Your Leadership. Organizational Dynamics. 3(4), 325-338.

Bandara, W., Syed, R., Ranathunga, B., \& Sampath Kulathilaka, K. B. (2017). People-Centric, ICT-Enabled Process Innovations via Community, Public and Private Sector Partnership, and e-Leadership: The Case of the Dompe hospital in Sri Lanka. In Business Process Management Cases (pp. 125-148). Springer, Cham. https://doi.org/10.1007/978-3-319-58307-5_8

Barrett, R. (2011). The New Leadership Paradigm.

Blau, I., \& Presser, O. (2013). e-Leadership of school principals: Increasing school effectiveness by a school data management system. British Journal of Educational Technology, 44(6), 1000-1011. https://doi.org/10.1111/bjet.12088

Bowen, E. E., Bertoline, G. R., Athinarayanan, R., Cox, R. F., Burbank, K. A., Buskirk, D. R., \& Küçükönal, H. (2013). Global Technology Leadership: A Case for Innovative Education Praxis. Procedia - Social and Behavioral Sciences, 75(3), 163-171. https://doi.org/10.1016/J.SBSPRO.2013.04.019.

Bums, J. S. (2016). Chaos Theory and Leadership Studies: Exploring Uncharted Seas. Journal of Leadership \& Organizational Studies, 9(2), 42-56. https://doi.org/10.1177/107179190200900204

Cano, L. F. (2010). Transformation of An Individual Family Community Nation and the World. Trafford Publishing.

Carraher, S. M. (2013). Strategy, leadership, emotional intelligence, and information. Journal of Technology Management in China, 8(2). https://doi.org/10.1108/JTMC-07-2013-0029

Cheung, R., \& Vogel, D. (2013). Predicting user acceptance of collaborative technologies: An extension of the technology acceptance model for e-learning. Computers \& Education, 63(63), 160-175. https://doi.org/10.1016/j.compedu.2012.12.003

Chin, R. J. (2015). Examining teamwork and leadership in the fields of public administration, leadership, and management. Team Performance Management: An International Journal, 21(3/4), 199-216. https://doi.org/10.1108/TPM-07-2014-0037

Chua, Y. P. Y. P., \& Chua, Y. P. Y. P. (2017). How are e-leadership practices in implementing a school virtual learning environment enhanced? A grounded model study. Computers \& Education, 109(109), 109-121. https://doi.org/10.1016/j.compedu.2017.02.012

Colbert, A. E., Judge, T. A., Choi, D., \& Wang, G. (2012). Assessing the trait theory of leadership using self and observer ratings of personality: The mediating role of contributions to group success. The Leadership Quarterly, 23(4), 670-685. https://doi.org/10.1016/j.leaqua.2012.03.004

Cook, J., \& Wall, T. (1980). New work attitude measures of trust, organizational commitment, and personal need non-fulfillment. Journal of Occupational and Organizational Psychology, 53(1), 39-52.

Damirchi, Q. V., Atafar, A., Rashidpour, A., \& Etebarian, A. (2014). Role of Culture in Leaders Leading. Kuwait Chapter of Arabian Journal of Business and Management Review, 3, 312-323.

Desveaux, L. (2015). The rise of leadership in physical therapy: a call to action. Physical Therapy Reviews, 20(56), 344-346. https://doi.org/10.1080/10833196.2016.1142163

Garcia, I. (2014). Emergent leadership: is e-leadership importance in the quality of virtual education? RIED. 
Revista Iberoamericana de Educación a Distancia, 18(1), 25-44. https://doi.org/10.5944/ried.18.1.13798

Graetz, F. (2000). Strategic change in leadership. Management Decision, 38(8), 550-564. https://doi.org/10.1108/00251740010378282

Gregoire, M. B., \& Arendt, S. W. (2014). Leadership: Reflections Over the Past 100 Years. Journal of the Academy of Nutrition and Dietetics, 114(5), S10-S19. https://doi.org/10.1016/J.JAND.2014.02.023

Hoch, J. E., \& Kozlowski, S. W. J. (2014). Leading virtual teams: Hierarchical leadership, structural supports, and shared team leadership. Journal of Applied Psychology, 99(3), 390-403. https://doi.org/10.1037/a0030264

Hurley, R. F. (2012). The decision to trust: How leaders create high trust organizations. San Francisco, CA: JoseyBass.

Iriqat, R. A. (2016). Organizational Commitment Role in Mediating the Impact of the Organizational Culture Dimensions on Job Satisfaction for MFIs' Employees in Palestine. International Journal of Business and Social Science, 7(5), 127-132.

Iriqat, R. A. M. (2017). Gender Leadership Styles in Enhancing Workforce Performance in Palestinian Public Institutions: The Role of Mediating Organizational Citizenship Behavior. International Review of Management and Business Research, 6(1), 93.

Iriqat, R. A., \& Khalaf, D. M. (2017). Using E-Leadership as a Strategic Tool in Enhancing Organizational Commitment of Virtual Teams in Foreign Commercial Banks in North West Bank -Palestine. International Journal of Business Administration, 8(7), 25. https://doi.org/10.5430/ijba.v8n7p25

Ismail, A., Mohamed, H. A. B., Sulaiman, A. Z., Mohamad, M. H., \& Yusuf, M. H. (2011). An empirical study of the relationship between transformational leadership, empowerment and organizational commitment. Business and Economics Research Journal, 2(1), 89.

Jameson, J. (2013). e-Leadership in higher education: The fifth "age" of educational technology research. British Journal of Educational Technology, 44(6), 889-915. https://doi.org/10.1111/bjet.12103

Jawadi, N., Daassi, M., Favier, M., \& Kalika, M. (2013). Relationship building in virtual teams: A leadership behavioral complexity perspective. Human Systems Management, 32(3), 199-211. https://doi.org/10.3233/HSM-130791

Keijser, W., Smits, J., Penterman, L., \& Wilderom, C. (2016). Physician leadership in e-health? A systematic literature review. Leadership in Health Services, 29(3), 331-347. https://doi.org/10.1108/LHS-12-2015-0047

Kesič, D., \& Shah, M. (2017). Strategic significance of products for pharmaceutical companies. Imperial Journal of Interdisciplinary Research, 3(3).

Keskes, I. (2014). The relationship between leadership styles and dimensions of employee organizational commitment: A critical review and discussion of future directions. Intangible Capital, 10(1). https://doi.org/10.3926/ic.476

Khan, M. S. (2012). Role of trust and relationships in geographically distributed teams: an Exploratory study on development sector. International Journal of Networking and Virtual Organizations, 10, 40-58. https://doi.org/10.1504/IJNVO.2012.045210

Laschinger, H. K. S., Finegan, J., \& Wilk, P. (2009). Context matters: The impact of unit leadership and empowerment on nurses' organizational commitment. Journal of Nursing Administration, 39(5), 228-235. https://doi.org/10.1097/NNA.0b013e3181a23d2b

Lee, P., Gillespie, N., Mann, L., \& Wearing, A. (2010). Leadership and trust: Their effect on knowledge sharing and team performance. Management Learning, 41(4), 473-491. https://doi.org/10.1177/1350507610362036

Lovelace, K. (2015). A Case Study of E-Leadership Constructs: An Assessment of Leadership in a Healthcare Organization. Doctoral Dissertations. The University of San Francisco.

Lu, L., Shen, C., \& Williams, D. (2014). Friending your way up the ladder: Connecting massive multiplayer online game behaviors with offline leadership. Computers in Human Behavior, 35, 54-60. https://doi.org/10.1016/J.CHB.2014.02.013

Lussier, R. N., \& Achua, C. F. (2015). Leadership: Theory, Application, \& Skill Development. Cengage Learning.

Luyegu, E. (2015). Instructional technology: Are you an E-Leader? Health Professions Educational Research Symposium, 17. 
Miller, D., \& Lee, J. (2001). The people make the process: commitment to employees, decision making, and performance. Journal of management, 27(2), 163-189. https://doi.org/10.1177/014920630102700203

Mozammel, S., \& Haan, P. (2016). Transformational leadership and employee engagement in the banking sector in Bangladesh. Journal of Developing Areas, 50(6), 43-55. https://doi.org/10.1353/jda.2016.0127

Olaisen, J., \& Revang, O. (2017). Working smarter and greener: Collaborative knowledge sharing in virtual global project teams. International Journal of Information Management, 37(1), 1441-1448. https://doi.org/10.1016/J.IJINFOMGT.2016.10.002

Pangil, F., \& Moi Chan, J. (2014). The mediating effect of knowledge sharing on the relationship between trust and virtual team effectiveness. Journal of Knowledge Management, 18(1), 92-106. https://doi.org/10.1108/JKM-09-2013-0341

Peñarroja, V., Orengo, V., Zornoza, A., Sánchez, J., \& Ripoll, P. (2015). How team feedback and team trust influence information processing and learning in virtual teams: A moderated mediation model. Computers in Human Behavior, 48, 9-16. https://doi.org/10.1016/J.CHB.2015.01.034

Podsakoff, P. M., MacKenzie, S. B., Moorman, R. H., \& Fetter, R. (1990). Transformational leader behaviors and their effects on followers' trust in leader, satisfaction, and organizational citizenship behaviors. The leadership quarterly, 1(2), 107-142.

Poliandri, V., Mattarelli, E., Bertolotti, F., Tagliaventi, M. R., \& Grandi, A. (2014). Integrating Knowledge through Consistency between Leadership and Technology in Distributed Teams. In Academy of Management Proceedings (Vol. 2014, p. 15767). Academy of Management. https://doi.org/10.5465/AMBPP.2014.15767

Qteishat, M. K. (2014). Factors Influencing the Adoption of E-Leader: An Empirical Field Study of Jordanian Banks. International Journal of Human Resource Studies, 4(3), 228. https://doi.org/10.5296/ijhrs.v4i3.6198

Remus, S. (2016). Advancing the Digital Health Discourse for Nurse Leaders. Studies in Health Technology and Informatics, 225, 412-416.

Salas, E., Shuffler, M. L., Thayer, A. L., Bedwell, W. L., \& Lazzara, E. H. (2015). Understanding and Improving Teamwork in Organizations: A Scientifically Based Practical Guide. Human Resource Management, 54(4), 599-622. https://doi.org/10.1002/hrm.21628

Savolainen, T. (2014). Trust-Building in e-Leadership: A Case Study of Leaders' Challenges and Skills in Technology-Mediated Interaction. Journal of Global Business Issues, 8(2), 45-56.

Suliman, A., Klaber, R. E., \& Warren, O. J. (2013). Exploiting opportunities for leadership development of surgeons within the operating theatre. International Journal of Surgery, 11(1), 6-11. https://doi.org/10.1016/J.IJSU.2012.11.002

Vaccaro, I. G., Jansen, J. J. P., Van Den Bosch, F. A. J., \& Volberda, H. W. (2012). Management Innovation and Leadership: The Moderating Role of Organizational Size. Journal of Management Studies, 49(1), 28-51. https://doi.org/10.1111/j.1467-6486.2010.00976.x

Walumbwa, F. O., Orwa, B., Wang, P., \& Lawler, J. J. (2005). Transformational leadership, organizational commitment, and job satisfaction: A comparative study of Kenyan and US financial firms. Human resource development quarterly, 16(2), 235-256. https://doi.org/10.1002/hrdq.1135

Wang, D., Waldman, D. A., \& Zhang, Z. (2014). A meta-analysis of shared leadership and team effectiveness. Journal of Applied Psychology, 99(2), 181-198. https://doi.org/10.1037/a0034531

Yukl, G. (2010). Leadership in Organizations. 7th ed., Pearson, New Jersey.

Zareen, M., Razzaq, K., \& Mujtaba, B. G. (2015). Impact of Transactional, Transformational and Laissez-Faire Leadership Styles on Motivation: A Quantitative Study of Banking Employees in Pakistan. Public Organization Review, 15(4), 531-549. https://doi.org/10.1007/s11115-014-0287-6

\section{Copyrights}

Copyright for this article is retained by the author(s), with first publication rights granted to the journal.

This is an open-access article distributed under the terms and conditions of the Creative Commons Attribution license (http://creativecommons.org/licenses/by/4.0/). 